\title{
Criança e infância na obra de Philippe Ariès e nos clássicos da História Social da Classe Operária: em busca das crianças invisíveis - as crianças proletárias
}

Jorge Fernando Hermida ${ }^{1}$

\begin{abstract}
Resumo
Neste artigo revelamos o lugar que as crianças proletárias tiveram nas representações dos conceitos de criança e de infância nos séculos XVII, XVIII e XIX na Europa, especialmente na obra de Philippe Ariès, pioneiro em pesquisar essa temática, ainda que, na sua obra seminal História social da criança e da família (2015), não tenhamos localizado nenhuma referência aos filhos da classe trabalhadora. Entretanto, a criança proletária teve presença social preponderante nas obras dos autores da História Social da Classe Operária, como será mostrado ao longo do texto, as quais abordavam a revolução industrial e a consolidação da formação social capitalista. Trata-se de uma pesquisa histórica e documental, com base em uma interpretação marxista da história. $\mathrm{O}$ artigo conclui que as representações de criança e infância de Ariès (2015) foram feitas com base em crianças pertencentes às classes dominantes da época (da nobreza e da aristocracia). Essas representações dos filhos das classes mais abastadas eram bem diferentes e bem distantes da efervescente vida social e da limitada vida material do resto das crianças - as crianças proletárias, que eram covardemente exploradas pelo capitalismo nos campos, nas fábricas, nas olarias e nas minas de carvão.
\end{abstract}

Palavras-chave: História social da criança proletária, Infância. Philippe Ariès, Capitalismo.

Child and childhood in the work of Philippe Ariès and in classes of Social History of the Working Class: in search of invisible children - proletarian children

\begin{abstract}
In this article we reveal the place that proletarian children played in representations of the concepts of child and childhood from the 17th, 18th and 19th centuries in Europe. The pioneer in researching these themes was Philippe Ariès. However, in his seminal work Social history of the child and the family (2015) we did not find any reference to the children of the working class. However, the proletarian child had a predominant social presence in the work of the authors of the Social History of the Working Class, who deal with the industrial revolution and the consolidation of capitalist social formation. It is a historical and documentary research, based on a Marxist interpretation of history. The article concludes that Ariès (2015) representations of children and childhood were based on children from the ruling classes of the time (nobility and aristocracy). These representations of the children of the wealthier classes were quite different and distant from the effervescent social life and limited material life of the rest of the children - the proletarian children, who were cowardly exploited by capitalism in the fields, factories, potteries and coal mines.
\end{abstract}

Keywords: Social history of the proletarian child, Childhood, Philippe Ariès, Capitalism.

\footnotetext{
${ }^{1}$ Uruguaio, naturalizado brasileiro. Doutorado em Educação pela Universidade Estadual de Campinas (UNICAMP). Professor Titular da Universidade Federal da Paraíba (UFPB) e Vice-coordenador do Programa de Pós-graduação em Educação (PPGE), da UFPB. Líder do Grupo de Estudos e Pesquisas Pedagogia Histórico-crítica, Políticas Públicas e Mundo do Trabalho - membro do HISTEDBR Nacional. Orcid: https://orcid.org/0000-0003-1963-463. E-mail: jorgefernandohermida@yahoo.com.br.
} 


\section{Introdução}

Pretende-se, neste artigo, contribuir para a composição de uma proposta de história social da criança proletária, tendo em vista que as visões, os sentidos e os conceitos de infância que hoje predominam no ambiente acadêmico, apoiados em interpretações e perspectivas idealistas e hibridas, parciais e descontextualizadas não consideraram, nas suas formulações, o importante lugar que tiveram os filhos da classe trabalhadora no processo de constituição da formação social capitalista, dos primórdios da Revolução Industrial até os dias atuais.

$\mathrm{Na}$ tese defendida para Professor Titular na Universidade Federal da Paraíba $\left(\right.$ HERMIDA, 2020a) ${ }^{1}$ e no artigo produto da tese (publicado recentemente) na Revista HISTEDBR On-line (HERMIDA, 2020b), ${ }^{2}$ problematizamos sobre a importância do tema. Ao analisar a vasta produção acadêmica nacional e internacional (artigos, capítulos de livros e livros), constatamos a existência de um denominador comum: mesmo existindo uma expressiva quantidade de publicações em diversas áreas e campos do conhecimento, a esmagadora maioria dos produtos acadêmicos que trata sobre os conceitos de criança e o sentimento de infância deixaram de lado àquelas crianças que faziam parte da ampla maioria das crianças da época: os filhos da classe operária. Isso é evidente quando nos debruçamos nos estudos de especialistas que pesquisaram sobre o assunto (ARIÈS e DUBY, 2009a, 2009b, 2009c, 2009d e 2009e; ARIÈS, 2015; KLEIN, 2012; KUHLMANN JUNIOR, 1998; LIMA, 2014; HERMIDA, 2020a e 2020b). Trata-se de algo contraditório e paradoxal pois, além de serem maioria dentre todas as crianças da época, os pequenos proletários foram um dos principais sujeitos históricos responsáveis pela alavancagem das mudanças econômicas e sociais ocorridas nos séculos XVII, XVIII e XIX, culminando na formação social que passou a ser predominante: a capitalista.

Dentre os principais cientistas sociais que se debruçaram sobre temas vinculados à criança e à infância, os quais contribuíram significativamente para o avanço das pesquisas nessa matéria, temos Philippe Ariès (1914-1984). Suas pesquisas foram inovadoras e

\footnotetext{
1 Tese defendida em 03/03/2020. Fizeram parte da banca os professores doutores José Claudinei Lombardi (UNICAMP), Silvio Ancízar Sánchez Gamboa (UFAL/UNICAMP), Inês Teixeira (UFMG), Dalila Oliveira (UFMG) e Charliton Machado (UFPB).

${ }^{2}$ Disponível em: https://periodicos.sbu.unicamp.br/ojs/index.php/histedbr/article/view/8660883.
} 
inauguraram uma nova perspectiva para as pesquisas sociais e históricas sobre criança e infância.

O rigor teórico e metodológico com que Ariès desenvolveu seus estudos e pesquisas para a composição da sua obra "História social da Criança e da Família" (2015) foi o que lhe permitiu defender a hipótese de que as crianças só passaram a ser objeto de preocupação das famílias, bem como a ser valorizadas, a partir do advento da sociedade industrial no século XVII. Essa nova realidade trouxe consigo a emergência de um sentimento de infância, paralelo à desconstrução da antiga sociabilidade feudal (ARIÈS, 2015). De fato, estavam assentadas as bases para a construção social do conceito de infância, e a obra de Ariès (2015) tornou-se referência obrigatória para temas vinculados à criança e à infância no Brasil.

$\mathrm{O}$ fato de reconhecermos publicamente os méritos de uma obra e de um autor, considerado clássico na historiografia e na sociologia da infância, não significa dizer que não existam algumas lacunas e pontos controversos. Na obra em questão, a não visibilidade dos filhos da classe trabalhadora (crianças proletárias) é um deles. Trata-se da não inclusão de um sujeito histórico que esteve muito presente na obra dos autores da História Social da Classe Operária (HOBSBAWM, 2001, 2005, 2015a, e 2015b; THOMPSON, 1987, 2012a, 2012b; DOBB, 1983; ENGELS, 2010 e MARX, 2010, 2013), por ter presença social preponderante na transição do século XVIII para o século XIX, justamente quando a triunfante revolução industrial assentava as bases firmes da formação social capitalista.

As considerações supracitadas nos conduziram à explicitação das seguintes questões norteadoras: por que as crianças proletárias não foram incluídas elou consideradas por Philippe Ariès na sua obra clássica "História Social da Criança e da Família”? Qual é o espaço que os pequenos operários ocupam nos relatos de historiadores marxistas que escreveram sobre a História Social da Classe Operária?

Neste artigo revelamos o lugar que as crianças proletárias tiveram, enquanto membros da nascente classe operária, nas representações dos conceitos de criança e de infância advindos dos séculos XVII, XVIII e XIX na Europa. ${ }^{3}$ Em termos teórico-metodológicos,

\footnotetext{
3 No que diz respeito à nomenclatura, utilizaremos as palavras criança proletária, pequenos operários, trabalhadores mirins e pequenos trabalhadores como sendo sinônimos. Essa foi a estratégia seguida por Friedrich Engels no livro A situação da classe trabalhadora na Inglaterra (2010), quando utilizou constantemente como sinônimos as palavras operários (working men), proletários, classe operária, classe não proprietária e proletariado.
} 
trata-se de uma pesquisa histórica e documental fundamentada em uma interpretação marxista da história. Para tanto, realizamos uma análise crítica do livro História social da criança e da família (ARIÉS, 2015) obra que, no dizer de Klein (2012) é seminal, tendo em vista a forte influência que a mesma teve e continua tendo na temática que envolve os conceitos de criança e de infância. Destacar as contribuições, e principalmente as limitações dessa obra, no que diz respeito às crianças proletárias é nossa prioridade. Logo procuramos aprofundar sobre o tema, selecionando e analisando outras fontes pictóricas da época, na tentativa de podermos constatar se as crianças filhas da classe trabalhadora faziam parte (ou não) das representações pictóricas da época. Pela sua relevância escolhemos obras de artistas europeus, que podem ser considerados clássicos da História da Arte: Pieter Bruegel, Giotto di Bondione, Philippe de Champaigne, Antoon van Dick e Diego Rodríguez Velázquez. Selecionamos imagens iconográficas (religiosas ou leigas), que retratavam crianças. A nossa intenção, nesta análise, foi verificar se as limitações da obra de Ariès (2015) vinculadas à observância (ou não) dessas crianças (filhas dos trabalhadores, portanto operárias) também estavam presentes nas obras pictóricas de outros renomados artistas da época.

A fim de situar o lugar das crianças proletárias neste período da história, confrontamos as contribuições de Ariès (2015) e o produto das suas análises de imagens iconográficas, com os relatos de historiadores marxistas que escreveram sobre a História Social da Classe Operária. Diferentemente de Ariès (2015), os relatos desses autores descreveram a presença marcante que essas crianças tiveram nessa época de profundas mudanças sociais, políticas e econômicas (HOBSBAWM, 2001, 2005, 2015a, e 2015b; THOMPSON, 1987, 2012a, 2012b; DOBB, 1983; ENGELS, 2010 e MARX, 2010, 2013).

A motivação para a escolha do assunto em questão, a partir da História Social da Classe Operária, deve-se ao viés acadêmico e político que o autor deste artigo pretende dar ao tema. Ao falar sobre história operária e ideologia, Hobsbawm (2015) nos lembra que a história operária tem, como princípio basilar, um compromisso político e acadêmico, o que faz com que a produção do conhecimento deva acontecer mesmo é dentro do movimento proletário, tendo em vista que “... a história ortodoxa não prestou atenção suficiente aos movimentos operários, e muito menos à classe operária" (HOBSBAWM, 2015a). Nesta perspectiva, 
O típico historiador da classe operária é um pesquisador ou professor universitário, embora isso também não seja sempre verdadeiro. Historiadores da classe operária, assim, situam-se num ponto de encontro entre os estudos acadêmicos e a política, entre compromissos de ordem prática e compreensão teórica, entre interpretar o mundo e transformá-lo (HOBSBAWM, 2015a, p. 15).

Fundamentado teórica e metodologicamente de acordo com os interesses da classe trabalhadora, este estudo vem para contribuir com uma visão de criança e de infância sob a perspectiva cultural histórico-proletária e sob a perspectiva educacional da Pedagogia Histórico-crítica, a fim de promover uma melhor compreensão do mundo e da construção de uma alternativa educacional emancipadora (SAVIANI, 2013). No dizer do pesquisador inglês: "Para muitos de nós o objetivo final de nosso trabalho é criar um mundo no qual os trabalhadores possam fazer sua própria vida e sua própria história, ao invés de recebê-la pronta de terceiros, mesmo dos acadêmicos" (HOBSBAWM, 2015a, p. 33).

O texto foi organizado em duas partes, além desta Introdução e das Considerações Finais. Na primeira parte, fazemos um resgate dos conceitos de criança e infância na obra de Philippe Ariès História Social da Criança e da Família (2015) e nos clássicos da História Social da Classe Operária: Hobsbawm (2015a; 2015b), Thompson (1987, 2012a, 2012b), Engels (2010) e Marx (2010, 2013). O resgate dos conceitos destaca as contribuições de cada uma das perspectivas, que se configuram como sendo antagônicas e diferentes. Este momento do artigo se encerra com uma pergunta, desafiadora, que norteia a construção textual da segunda parte que, ao tratar das crianças e sua infância em tempos de profundas mudanças sociais, problematiza sobre o importante papel que coube aos trabalhadores mirins nas conquistas sociais advindas das contradições sociais existentes na nascente formação social capitalista.

Criança e infância em Philippe Ariès e nos clássicos da História Social da Classe Operária

O interesse pelas crianças e suas infâncias não foi uma qualidade sempre presente no transcurso da história da humanidade. Muito pelo contrário. Foi preciso esperar até o século XVII para que as crianças adquirissem maior visibilidade e com isso se tornassem objeto de 
estudo, com foco em temas como criança, infância e família (ARIÈS; DUBY, 2009a, 2009b, 2009c, 2009d e 2009e; ARIÈS, 2015; HERMIDA, 2020a e 2020b).

Conforme foi comentado na Introdução, dentre os principais cientistas sociais do século XX que tiveram como objeto de estudo temas vinculados a crianças e infâncias desde uma perspectiva multidisciplinar, temos o francês Philippe Ariès (1914-1984). Os estudos desenvolvidos por Ariès foram inovadores e inauguraram uma nova perspectiva para as pesquisas sociais e históricas, que tiveram como objeto principal de estudo a criança, a infância, a família e a juventude. Utilizando monumentos, túmulos, registros de batismo, diários de família e principalmente imagens iconográficas (religiosas e leigas) como fonte de pesquisa, o historiador e sociólogo francês teve o grande mérito de transformar a criança e suas famílias em objetos de investigação historiográfica. Essa característica fez de Philippe Ariès um dos clássicos mais estudados nos cursos de Pedagogia e de formação de professores nas instituições de ensino superior no Brasil.

A sua obra clássica, intitulada "História Social da Criança e da Família" (2015), publicada na Franca em 1960 e nos Estados Unidos da América em 1962 causou grande impacto mundial, tendo se tornado referência obrigatória sobre o assunto. Pioneiro na matéria, motivou mundialmente numerosos pesquisadores a investigar sobre criança e infância, seja adotando (os mais) ou refutando (os menos) suas teses. De uma forma ou de outra, não podemos deixar de citar o clássico de Ariès (2015) cada vez que nos pronunciemos academicamente sobre o tema criança e infância. No texto, o autor defende duas teses:

- A velha sociedade tradicional não via com bons olhos a criança, e ainda pior o adolescente. A criança existia, mas não era reconhecida como nos moldes atuais. E,

- A partir de um certo período, no século XVII, com o advento da sociedade industrial uma mudança considerável alterou o estado das coisas, e as crianças começaram a ser objeto de preocupação das famílias, passando a ser valorizadas. Com a emergência de um novo sentimento de infância, ocorre a desconstrução da antiga sociabilidade (ARIÈS, 2015).

Em síntese: se bem as crianças sempre existiram, o conceito de infância foi uma invenção da Europa Ocidental nas origens da modernidade. 
Até por volta do século XII, a arte medieval desconhecia a infância ou não tentava representa-la. É difícil crer que essa ausência se devesse à incompetência ou à falta de habilidade. É mais provável que não houvesse lugar para a infância neste mundo (...) Tal é nosso ponto de partida. Como daí chegamos às criancinhas de Versalhes, às fotos de crianças de todas as idades dos nossos álbuns de família? (ARIÈS, 2015, p.17-8).

A utilização de imagens iconográficas religiosas e leigas como fonte de pesquisa foi uma inovação que Ariès (2015) trouxe para o campo dos estudos e pesquisas sobre crianças e infância. No entanto, a análise pormenorizada de sua obra nos permite reconhecer, além dos méritos supracitados, uma limitação relevante: suas análises sempre estiveram direcionadas para a pesquisa de crianças e infâncias que faziam parte de famílias nobres, aristocráticas e burguesas. Ao descrever os jogos, as brincadeiras e os costumes das crianças da época (séculos XVII, XVIII e XIX) utilizando diversas fontes de pesquisa, as crianças analisadas sempre eram as mesmas. Ao falar sobre representações pictóricas, Ariès (2015) comentou:

\footnotetext{
Numa gravura de Abraham Bosse representando as quatro idades do homem, a infância é sugerida pelo que hoje chamamos de nursery: um bebê no berço vigiado por uma irmã atenta, uma criança de túnica mantida de pé numa espécie de cercado com rodas (objeto muito comum entre os séculos XV e XVIII), uma menina com sua boneca, um menino com um cata-vento, e dois meninos maiores preparando-se para brigar, tendo um deles jogado no chão seu chapéu e sua capa. A virilidade é ilustrada pela refeição que reúne a família em torno da mesa, numa cena análoga `de vários retratos, e que seria muitas vezes repetida tanto na gravura francesa como na pintura holandesa (ARIÉS, 2015, p. 208).
}

Essa realidade familiar e social contrasta com a descrição que Marx (2010; 2013), Engels (2010), Thompson (2012a e 2012b) e Dobb (1983) fizeram dos lares proletários nas suas obras e pesquisas. Por exemplo, ao tentar descrever a questão social das famílias que moravam num dos bairros proletários mais populosos da cidade de Londres (St. Giles), Engels (2010) escreveu o seguinte:

As casas são habitadas dos porões aos desvãos, sujas por dentro e por fora e têm um aspecto tal que ninguém desejaria morar nelas. Mas isso não é nada, se comparado às moradias dos becos e vielas transversais, aonde se chega através de passagens cobertas e onde a sujeira e o barulho superam a imaginação: aqui é difícil encontrar um vidro intacto, as paredes estão em ruínas, os batentes das portas e os caixilhos das janelas estão quebrados ou descolados, as portas - quando as há - são velhas pranchas pregadas umas às outras, mas, nesse bairro de ladrões, as portas são inúteis, nada há para roubar (ENGELS, 2010, p. 71). 
A degradação econômica, material e moral atingia todos os níveis imagináveis, porque:

\begin{abstract}
Aqui vivem os mais pobres entre os pobres, os trabalhadores mais mal pagos, todos misturados com ladrões escroques e vítimas da prostituição. A maior parte deles são irlandeses, os seus descendentes, e aqueles que ainda não submergiram totalmente no turbilhão da degradação moral que os rodeia a cada dia mais se aproximam dela, perdendo a força para resistir aos influxos aviltantes da miséria, da sujeira e do ambiente malsão (ENGELS, 2010, p. 71).
\end{abstract}

Evidentemente, essas crianças eram facilmente encontradas trabalhando nos complexos fabris, nas olarias, no campo e nas minas de carvão do que nos seus próprios lares. Hobsbawm (2015a; 2015b), Thompson (1987, 2012a, 2012b), Engels (2010) e Marx (2010, 2013) nos lembram que a nascente sociedade burguesa foi assentando suas bases em um processo de transição que não era linear, mas sim cheio de conflitos e interações. $O$ desenvolvimento econômico da burguesia (e seus aliados) nos primórdios da Revolução Industrial baseou-se em processos de exploração e superexploração da farta mão de obra barata provida pelos lares proletários, onde além dos homens, suas mulheres e posteriormente seus filhos foram sendo inseridos nos processos produtivos perversos da revolução econômica em curso.

A avassaladora revolução industrial era concomitante à consolidação da formação social capitalista e não deixava opções para aqueles que migravam do campo para as cidades. $\mathrm{Na}$ época, “...havia frequentes recrutamentos forçados de mão-de-obra para estabelecimentos privilegiados de todos os tipos, e os pais que não mandassem os filhos para a indústria eram ameaçados com multas pesadas" (DOBB, 1983, p. 169).

Para Thompson (2012a, p. 255), o trabalho infantil não era uma novidade, já que:

A criança era uma parte intrínseca da economia industrial e agrícola antes de 1780, e como tal permaneceu até ser resgatada pela escola. Certas ocupações - como a dos limpadores de chaminés ou a dos garotos empregados em navios - eram provavelmente piores do que as funções mais árduas desempenhadas nas primeiras fábricas; um órfão entregue como "aprendiz" pela paróquia a um Peter Grimes ou a um carvoeiro bêbado, em algum "antro", estava submetido a um tratamento cruel, num isolamento ainda mais terrível.

Com o advento das máquinas e o aparecimento de novas fontes de energia, a substituição da força de trabalho dos homens pela força de trabalho das mulheres e crianças 
tornou-se inevitável - mesmo que estas últimas fossem crianças pequenas. Isto chegou ao paradoxo quando passa a fazer parte do mercado de trabalho a família inteira do trabalhador. A inserção das crianças no mundo produtivo era vista com naturalidade, se considerarmos os dados demográficos dos principais países europeus (Inglaterra e França): na época, duas de cada cinco pessoas eram menores de 18 anos. Na transição secular (XVIII para o XIX), 40\% dos ingleses e franceses eram crianças.

Conforme descrito por Marx (2013), com as evoluções tecnológicas as máquinas chegaram às fábricas, o que possibilitou o emprego de trabalhadores sem a necessidade de força física - leia-se, mulheres e crianças. "À medida que torna prescindível a força muscular, a maquinaria converte-se no meio de utilizar trabalhadores com pouca força muscular ou desenvolvimento muscular imaturo, mas com membros de maior flexibilidade. Por isso, o trabalho feminino e infantil foi a primeira palavra de ordem da aplicação capitalista da maquinaria!" (MARX, 2013, p. 468).

Nessa nova realidade perversa para os interesses da classe trabalhadora, a demanda por trabalho infantil se assemelhava à demanda por escravos negros. E mais, a exploração dos trabalhadores mirins, associada à inexistência de limites legais em relação ao excesso e ao prolongamento da jornada de trabalho, não ficava aquém “...das crueldades dos espanhóis contra os peles-vermelhas da América" (MARX, 2013, p. 317). A "voracidade de lobisomem" por mais trabalho ocorria em todos os ramos da indústria inglesa, desde as fábricas de Manchester, as olarias de Stanffordshire, a manufatura de palitos de fósforo de Nottingham, as tinturarias e as minas de carvão dos condados de Northumberland e Durhham. A constante era sempre a mesma: mulheres e crianças engrossando as fileiras dos explorados do sistema. Referindo-se à força de trabalho das crianças desde sua tenra idade, Marx (2013) cita uma matéria publicada no Daily Telegraph de Londres de (17/01/1860), onde se pode ler:

O sr. Broughton, county magistrate declarou (...) na Câmara Municipal de Nottingham, em 14 de janeiro de 1860, que entre a população ocupada com a fabricação de rendas reina um grau de sofrimento e privação inéditos no restante do mundo civilizado (...) Crianças entre 9 e 10 anos de idade são arrancadas de suas camas imundas às 2, 34 horas da manhã e forçadas a trabalhar, para sua mera subsistência, até as 10,11, 12 horas da noite, enquanto seus membros se atrofiam, seus corpos definham, suas fases desbotam e sua essência humana se enrijece inteiramente num torpor pétreo, cuja mera visão já é algo terrível (MARX, 2013, p. 317). 
É sabido que o revolucionar das forças produtivas e os avanços tecnológicos trouxeram progressos materiais para a sociedade da época. Porém, o ônus dos seus piores e mais perversos efeitos residuais foi pago por àqueles que faziam parte da força viva do processo, colocados no elo mais fraco do sistema: o proletariado, e principalmente seus filhos e esposas, como acontece até hoje, inclusive, ainda que com outra configuração.

Diante do exposto, não temos mais como desconhecer o papel protagonista da criança e de sua infância enquanto categorias ativas e participativas da construção da realidade social nos séculos XVII, XVIII e XIX. A mudança acontecida em torno da criança proletária foi uma das tantas causas que conduziram à humanidade a trilhar um processo civilizatório, que teve desdobramentos nas relações sociais e familiares, nas relações trabalhistas, na emergência das primeiras leis laborais e nas primeiras preocupações com cuidados vinculados à saúde no trabalho. No entanto, as análises desenvolvidas por Ariès (2015), se omitiram dessa importante realidade. Pairando, desta maneira, a seguinte pergunta: por que essas crianças (trabalhadores mirins) não foram visualizadas por Philippe Ariès?

\section{Crianças e infância em tempos de mudança social: cadê as crianças proletárias?}

O ponto de partida para nossa análise documental e histórica de como as crianças proletárias foram (ou não) representadas nas imagens iconográficas utilizadas por Ariès (2015) e outros artistas da época se localiza nas origens da própria classe operária e no interior da formação social capitalista. Com o advento da Revolução Industrial e da Revolução Francesa, antigos paradigmas econômicos e sociais da sociedade feudal foram eliminados e, decorrência disso, ocorreram profundas mudanças sociais. Com as mudanças ocorridas nos modos de produção, nas instituições e no mundo material, um novo ethos social começa a configurar-se desencadeando, também, mudanças nas mentalidades e subjetividades. Uma nova sociedade começava a ser construída, caótica e freneticamente (HOBSBAWM, 2001; 2005; 2015a). É justamente na base desse processo de mudanças que se alicerçam os pilares da modernidade. Nesse novo cenário, acontece a emergência de um novo sentimento de infância.

Conforme destacamos, a pesquisa histórica e sociológica com base em fontes vinculadas à arte pictórica foi introduzida por Ariès (2015) por ser socialmente valorizada entre as classes mais abastadas tanto na Idade Média quanto no capitalismo. Ainda que o 
estudo de Ariès (2015) seja considerado inédito e original, suas análises sempre estiveram direcionadas à pesquisa sobre crianças de famílias nobres e aristocráticas. Felizmente, os artistas escolhidos para suas análises não foram os únicos que se preocuparam com o registro de crianças e infâncias.

Um pintor valorizado por ser considerado um dos mais expressivos do século XVI e XVII é Pieter Bruegel O Jovem (1564-1639). ${ }^{4}$ Ele proporcionou imagens iconográficas que representavam fielmente a dinâmica social do camponês, desde cenas e situações quotidianas até suas festas, paisagens, temas religiosos e fantasias (https://pt.wahooart.com/A55A04/w.nsf/O/BRUE-8LT57K). Sua arte teve a virtude de revigorar temas medievais desde a perspectiva do grotesco camponês situado em contextos paisagísticos, muitas vezes aparentemente anárquicos.

Figura 1 - A quermesse de São Jorge (1628), de Pieter Bruegel The Younger (1564-1639)

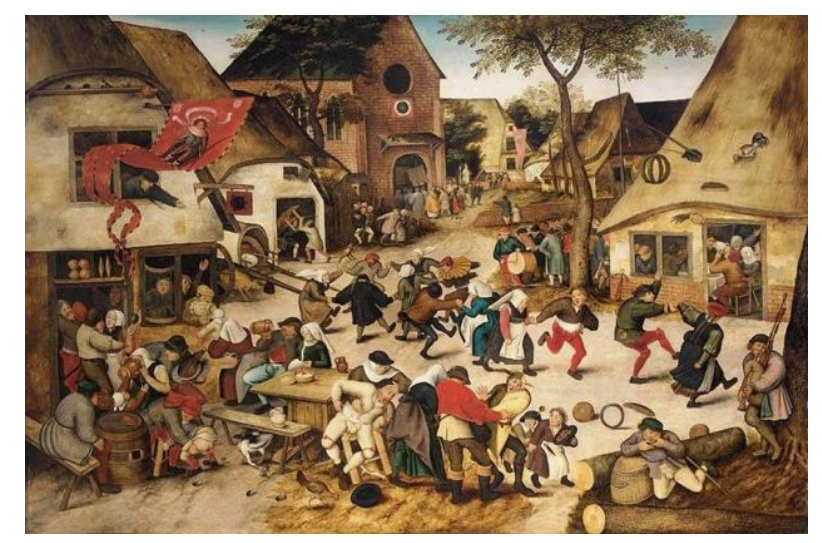

Fonte: https://pt.wahooart.com/A55A04/w.nsf/O/BRUE-8LT57K

Voltando-nos para o tema da infância e a criança da época medieval, constatamos na imagem iconográfica a presença de crianças em cenários do quotidiano da época. Elas aparentam vivenciar plenamente suas infâncias, marcando forte presença e ocupando todos os espaços sociais medievais. Neste termo coincidimos com a análise realizada por Ariès (2015) e suas hipóteses explicativas:

\footnotetext{
${ }^{4}$ Pieter Bruegel O Jovem (1564-1639), era filho mais velho do famoso Netherlandish Pieter Bruegel $O$ Velho (1525?-1569), o artista mais importante da pintura renascentista flamenga e brabantina. Eles sempre pintaram cenas camponesas e paisagens da região onde moravam (região de Bravante, hoje localizada na Bélgica).
} 
... primeiro, a de que na vida quotidiana as crianças estavam misturadas com os adultos, e toda reunião para o trabalho, o passeio ou o jogo reunia crianças e adultos; segundo, a ideia de que os pintores gostavam especialmente de representar a criança por sua graça ou por seu pitoresco (o gosto do pitoresco anedótico desenvolveu-se nos séculos XV e XVI e coincidiu com o sentimento da infância "engraçadinha"), e se compraziam em sublinhar a presença da criança dentro do grupo ou da multidão (ARIÉS, 2015, p. 31).

Em A quermesse de São Jorge, de 1628, temos oportunidade de observar cenas da vida quotidiana, com crianças e adultos interagindo. Deixando claro como crianças da época marcavam presença na festa religiosa ludicamente representada. Imagem predominante na Idade Média, ela apresenta uma caracterização de crianças e suas infâncias bem distante daquelas representações de criança e infância dos dias de hoje. As iconografias de pessoas de menor tamanho vivenciando situações lúdicas seriam imagens de crianças - mesmo que elas apareçam vestidas como adultos em miniatura. Essa forma de representar as crianças era predominante na Idade Média. “Apenas seu tamanho os distinguia dos adultos” (2015, p. 17).

A representação de crianças através de imagens religiosas precedeu o desenho de adultos em miniatura na Idade Média. Mesmo assim, as imagens apresentavam constantes já descritas, já que o rosto do menino Jesus não tem nada de menino, e sim de um rosto de adulto (fig.2). O gesto da mão do menino encena uma espécie de cumprimento, intencional, para os potenciais espectadores. Sempre havia elementos comuns nas representações da Idade Média: rostos e corpos de crianças com traços, vestimentas e morfologia de adultos.

Figura 2 - Detalhe del quadro Madonna di San Giorgio alla Costa (1295), de Giotto di Bondone (1267-1337)

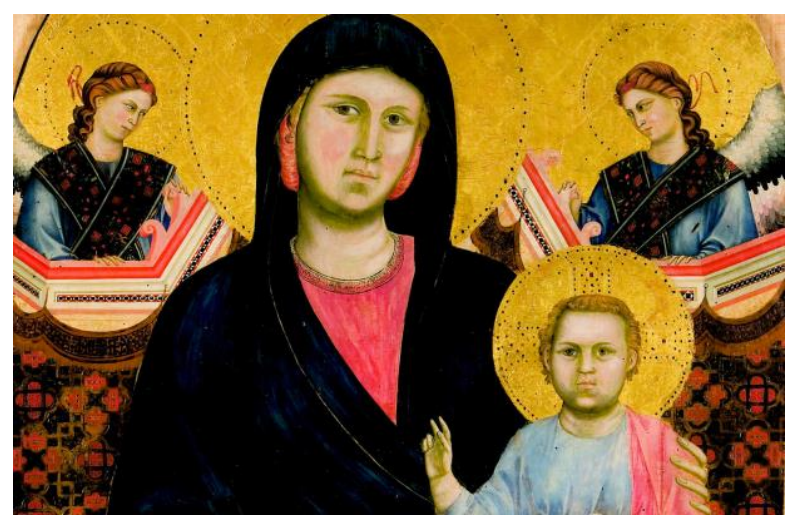

Fonte: https://www.firenzeyesplease.com/en/post/un-capolavoro-di-giotto/ 
O detalhe da pintura do fiorentino Giotto di Bondone (1267-1337) continuará se fazendo presente em outras obras de arte de natureza religiosa até fins do século XVIII (ver fig. 3).

\section{Figura 3 - Antiga pintura italiana religiosa do século XVIII (autor desconhecido)}

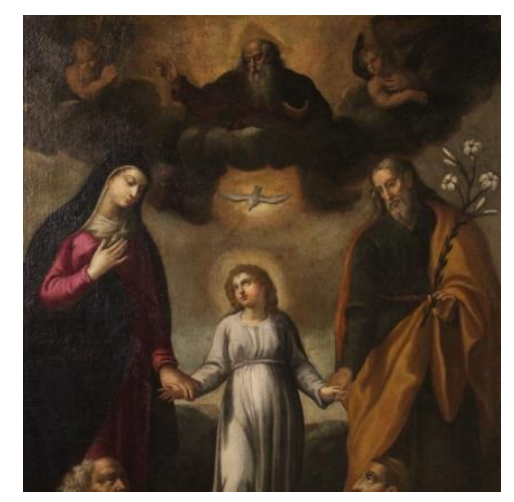

Fonte: https://www.anticoantico.com/pt/items/225238/Pintura-religiosa-italiana-antiga-do-s-culoXVIII?\#\&gid=gallery $1 \&$ pid $=1$.

Com o passar do tempo, a representação de crianças adquire os requintes da nobreza. As imagens iconográficas vinculadas ao camponês em situações quotidianas e aquelas vinculadas a motivos religiosos, dão espaço a representações nobres e aristocráticas. Com a valorização que tiveram os retratos entre os séculos XVII e XIX, passou a ser comum que a as classes dominantes quisessem retratar seus familiares. Rostos e corpos de crianças, com vestimentas e traços morfológicos de adultos incorporam detalhes das classes dominantes.

Esses detalhes pertencentes ao mundo dos adultos também são percebidos na imagem de Philippe Champaigne (1602-1674). A tendência de retratar detalhes das classes dominantes (status quo) se consolida. Na obra do mais brilhante retratista francês a serviço da nobreza, intitulada Les Enfants Herbert de Montmort, podemos observar que tanto aparências quanto vestimentas, apresentam atitudes genuinamente adultas. Os meninos do lado esquerdo do quadro apresentam posturas adultas. Os olhares despreocupados e despretensiosos indicam que são filhos de famílias detentoras do poder, materialmente despreocupadas (ver figura 4). 
Figura 4 - Les enfants Herbert de Montmort (1649), de Philippe de Champaigne (16021674)

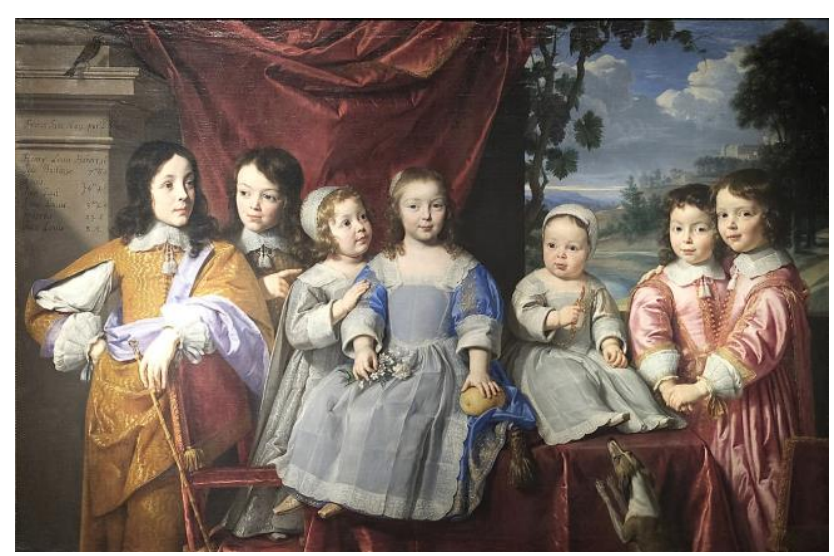

Fonte:

https://commons.wikimedia.org/wiki/File:F3524_Reims_musee_Philippe_de_Champaigne_Enfants_Habert_de_ Montmort_rwk.jpg.

As primeiras propostas sociais e educacionais direcionadas às crianças pobres e abandonadas começam a aparecer na transição do feudalismo para o capitalismo. A sala de asilo francesa tinha como cometido retirar as crianças abandonadas das ruas, que estavam em situação de risco, para proporcionar-lhes educação moral, intelectual e ensinar-lhes bons costumes (KUHLMANN Jr, 1998). Vale ressaltar, contudo, que maior do que a preocupação com as crianças em si, o que verdadeiramente motivava esse tipo de ações era tirar as crianças das ruas para deixar as cidades mais limpas.

Com o advento do Renascimento e motivados por ideias iluministas, as preocupações vinculadas com as crianças adquirem um novo patamar (século 17). Inicia-se um processo de mudanças que inaugura uma nova concepção de homem, baseada na sua dimensão racional. Nesse âmbito ideológico-cultural, a modernidade opera um duplo processo: de laicização (a mente se emancipa da visão religiosa do mundo), e de racionalização, pois há uma revolução de saberes que passam a ser legitimados e organizados pelo uso da razão (CAMBI, 2001). Uma grande mudança interveio então nessa sociedade, na transição do feudalismo em direção a sua completa extinção, que afetou a educação e a transmissão de saberes e valores. Que inclusive teve desdobramentos no âmbito da educação (ARIĖS, 2015). Na opinião do autor,

A partir do século $\mathrm{XV}$, as realidades e os sentimentos da família se transformariam: uma revolução profunda e lenta, mas percebida tanto pelos contemporâneos como 
pelos historiadores, e difícil de reconhecer (...) Vimos que na Idade Média a educação das crianças era garantida pela aprendizagem junto aos adultos, e que, a partir de sete anos, as crianças viviam com uma outra família que não a sua. Dessa época em diante, ao contrário, a educação passou a ser fornecida cada vez mais pela escola. A escola deixou de ser reservada aos clérigos para se tornar um instrumento normal de iniciação social, da passagem do estado da infância ao adulto (ARIÈS, 2015, p. 159).

O conceito que emana da obra de Ariès (2015) não se referenciou nas crianças comuns, pobres e com limitações culturais. Mesmo assim, é possível identificar a emergência de um novo sentimento, o sentimento de infância, até então inexistente na vida social. Ela serviria como contraponto para a perspectiva da história social da criança proletária.

\section{Figura 5 - Os cinco filhos mais velhos de Carlos I (1637), de Antoon van Dick (1599- 1641)}

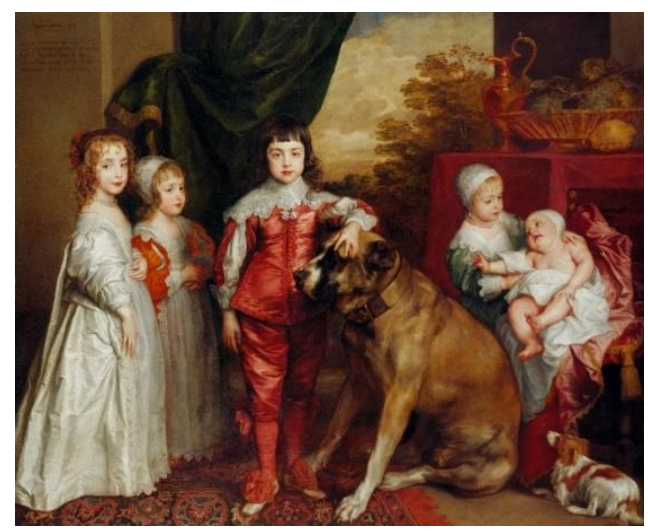

Fonte: https://pt.wikipedia.org/wiki/Ficheiro:Anthony_van_Dyck_-_Five_Eldest_Children_of_Charles_I__Google_Art_Project.jpg\#file.

Essa tendência de conceber a criança também é representada na obra de Antoon van Dick (1599-1641), intitulada Os cinco filhos mais velhos de Carlos I (fig. 5). O quadro de van Dick $^{5}$ apresenta fielmente como as crianças eram concebidas pela nobreza. Nela aparecem os cinco filhos de Carlos I: Maria, Jaime, Carlos, Isabel e Ana. Governador polêmico, o Rei da

\footnotetext{
${ }^{5}$ Antoon van Dick (1599-1641) foi outro pintor que nasceu na região de Brabante (hoje na Bélgica e Países Baixos). Discípulo de Rubens, van Dick também trabalhou na sua juventude com Pieter Bruegel O Jovem. Nessa época ele estava proibido de vender seus quadros porque não era mestre. Fato que se concretiza anos mais tarde. Como frequentava ambientes de gente endinheirada, van Dick decide adotar a sociabilidade aristocrática, para a qual começa a compor.
} 
Inglaterra acreditava na ideia do direito divino dos reis, ${ }^{6}$ e isso fez com que seu reinado somasse disputas frente à força do parlamento inglês. A representação de crianças nobres, mas em um contexto político e cultural diferente, também está presente em Las Meninas de Velázquez (em português, "meninas" = "damas de honra"), de autoria do pintor espanhol Diego Rodríguez de Silva y Velázquez (1599-1600).

\section{Figura 6 - Las meninas de Velázquez (1656), de Diego Rodríguez, de Silva y Velázquez (1599-1660)}

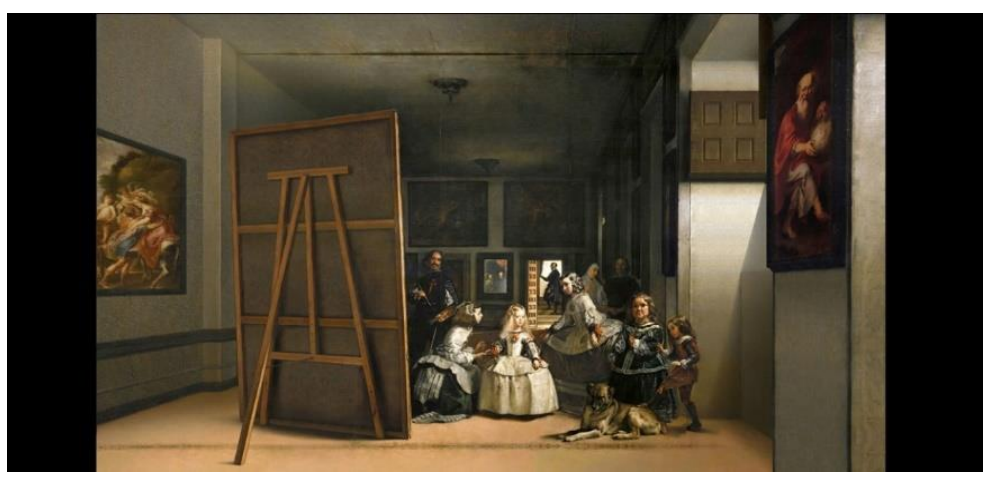

Fonte: http://www.arteeblog.com/2016/04/analise-de-las-meninas-de-diego.html.

Velázquez foi um pintor que ficou famoso pelos retratos que ele fez da família real no reinado do rei Filipe IV da Espanha. O artista representou na tela uma cena familiar, que tem a Infanta Margarida Teresa como principal protagonista, rodeada de personagens da corte: damas de companhia, guardião, duas anãs e um cão de estimação. No quadro Velázquez pintou personagens que comumente não fazem parte de obras desta natureza, como por exemplo, o próprio pintor (com pincel em mão e palheta), e os pais da Infanta (o rei Filipe e a rainha Mariana de Áustria), que aparecem refletidos no espelho localizado ao lado da porta.

Velázquez foi considerado um dos pintores mais importantes do Século de Ouro espanhol. ${ }^{7} \mathrm{O}$ quadro Las Meninas alcançou fama mundial pelas complexidades e seu jogo de perspectivas. Por conta disto, tornou-se uma das figuras iconográficas mais estudadas e

\footnotetext{
${ }^{6}$ Tratava-se de uma doutrina moral e religiosa, que se baseava na ideia de que os reis na terra e suas decisões tinham fundamento divino e representavam a vontade de Deus. Como produto do seu tempo, a teoria do direito divino dos reis só conseguiu subsistir em estados teocráticos, como por exemplo, o Estado do Vaticano e outras modalidades de estados, a exemplo dos Califados decorrentes do Islã e o seu texto fundante: o Alcorão, ou Corão (Fonte: https://pt.wikipedia.org/wiki/Direito_divino_dos_reis).

${ }^{7} \mathrm{O}$ século de ouro espanhol foi uma época da história da arte espanhola, que teve artistas de diversas áreas (pintores, escultores, escritores), que produziram obras hoje consideradas clássicas. O século de ouro abrangeu o Renascimento do século XVI e o Barroco do século XVII. Foi uma época de auge cultural, político e militar.
} 
reconhecidas da História da Arte ocidental e mundial. A Infanta Margarida também foi retratada por Velázquez seis anos mais tarde, em 1656 (figura 7). Os detalhes de suas roupas demonstram ser elas inapropriadas para crianças. Mas na nobreza isso era comum. As figuras 5, 6 e 7 apresentam um denominador comum: elas pertencem a contextos e culturas diferentes e representam a filhos de reis das mais importantes monarquias da Europa (Inglaterra e Espanha).

\section{Figura 7 - A infanta Margarida (1656), de Diego Velázquez (1599-1660)}

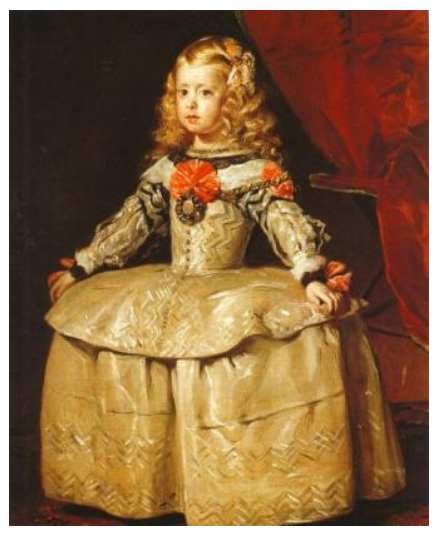

Fonte: https://lilimachado.wordpress.com/2012/07/14/a-infanta-margarita-paniers/.

O conjunto das obras de van Dick e Velázquez representam as crianças como adultos em miniatura. Roupas, morfologia, gestos e até olhares indicam a concepção e o sentimento de infância que predominava entre as classes mais abastadas. As composições apresentam o luxo que caracterizava o cotidiano dos filhos dos reis, da nobreza e da aristocracia. Mas sabemos também que fora dos muros dos palácios e castelos, a vida acontecia em ritmo vertiginoso, em efervescência, em decorrência das mudanças sociais e econômicas da época.

No fim das contas, havia uma revolução social em curso! Enquanto as crianças da nobreza e da aristocracia deambulavam pelos corredores de palácios, jardines, castelos e casarões, a ampla e esmagadora maioria das crianças, filhos de camponeses e principalmente da classe operária, vivenciava as consequências perversas da revolução industrial, pois elas também passaram a ser exploradas pela burguesia capitalista no sistema fabril, nas olarias, nas minas de carvão e em outros trabalhos urbanos, como por exemplo, de varredor de chaminés na cidade de Londres. 
Se houve um personagem que representava as dores dos pequenos ao serem inseridos no sistema fabril e na indústria, ele foi, sem dúvidas, o varredor de chaminés. A limpeza de chaminés foi um trabalho tradicional que existia desde o século XII, e adquiriu notoriedade nos séculos XVII e XVIII - em plena era vitoriana. O aumento da demanda por esse trabalho (que no início era realizado por homens), fez das crianças pequenos objetos de desejo, principalmente quando eram crianças pobres. Como se tratava de um trabalho sujo, exigente, perigoso, era difícil que uma criança aceitasse por livre e espontânea vontade fazê-lo. A solução encontrada pelos adultos para conseguir os pequenos ajudantes para fazer as varreduras de chaminés foi comprar as crianças dos próprios pais, ou ainda, tomar posse deles nos orfanatos pela força, sequestrando-os. Para Thompson (2012a, p. 253),

O trabalho infantil não era uma novidade. A criança era uma parte intrínseca da economia industrial e agrícola antes de 1780 , e como tal aparece até ser resgatada pela escola. Certas ocupações - como a dos limpadores de chaminés ou a dos garotos empregados em navios - eram provavelmente piores do que as funções mais árduas desempenhadas nas primeiras fábricas.

Tendo em vista que o trabalho fabril submetia os pequenos a jornadas de trabalho só equiparáveis a maratonas, cujas consequências atentavam contra a integridade física e moral dessas crianças, imaginemos então o que ocorria no interior das minas de carvão... Dentre os que mais sofriam as consequências da revolução industrial certamente estava a classe de trabalhadores mirins das minas de carvão!

O trabalho nas minas de carvão era uma modalidade totalmente insalubre, análoga ao trabalho escravo, dos séculos XVIII e XIX. Ocorria em estreitas galerias subterrâneas, quentes, mal iluminadas e muito menos arejadas. Em condições totalmente adversas, trabalhadores e crianças conseguiam extrair mais de 100 milhões de toneladas de carvão por ano. Além de ser apenas uma consequência da era das máquinas, as minas de carvão foram sua causa. 


\section{Figura 8 - Crianças na mina de carvão no século XIX}

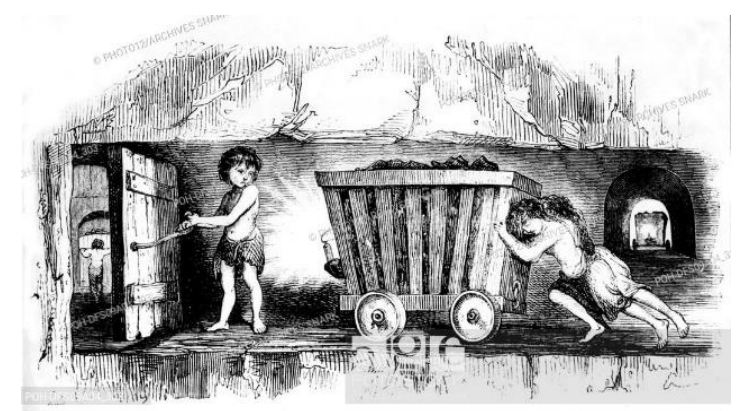

Fonte: https://www.agefotostock.com/age/en/Stock-Images/Rights-Managed/POH-DFS09A04_303.

Crítico ferrenho da situação desumana de exploração que as crianças proletárias vivenciavam desde sua tenra idade, Marx (2013) afirmou que "A demanda por trabalho infantil se assemelha com frequência, também em sua forma, à demanda por escravos negros, como se costumava ler em anúncios de jornais americanos” (p. 469-470). Resta claro, portanto, que a preocupação do capitalista industrial passava longe de temas, como por exemplo, a saúde dos seus trabalhadores. Quiçá esse tipo de preocupação também passou longe de Philippe Ariès.

\section{Considerações finais}

A iniciativa de pesquisar este tema foi motivada pelo nosso desejo de dar mais visibilidade a um sujeito histórico (a criança proletária) e a um período de seu desenvolvimento (a sua infância), que via de regra tem sido submetido, no transcurso da própria evolução da humanidade, a uma condição de "não visibilidade", tendo em vista os primorosos relatos de muitos pesquisadores, historiadores e cientistas sociais marxistas que se debruçaram sobre o tema da História Social da Classe Operária. Nas obras dessa perspectiva, encontramos relatos sobre as dificuldades e sofrimentos que os filhos da classe trabalhadora passaram nesses tempos de profundas mudanças sociais e políticas.

Concordamos com o pesquisador francês quando ele afirma que, se por um lado, as crianças faziam parte da dinâmica societária em diversos momentos da história da própria humanidade, por outro, elas só adquirem nova visibilidade a partir do século XVII, pois não existia até esse momento um sentimento de infância, conforme o que entendemos por criança 
nos dias de hoje. $\mathrm{O}$ autor consegue descrever a história das categorias criança e adolescência na passagem da sociedade feudal para a sociedade capitalista. No entanto, na pesquisa realizada por Ariès (2015) não encontramos qualquer tipo de referência aos filhos da classe trabalhadora.

Nesse sentido, concluímos o seguinte: o papel que coube aos trabalhadores mirins precisa ser redimensionado, uma vez que a sua presença em todos os espaços sociais (parques, praças, ruas, olarias, minas de carvão e fábricas), associada à emergência de ideias humanistas renascentistas e principalmente às conquistas civis e políticas obtidas na Revolução Francesa, contribuíram para a emergência de um novo ethos social.

O reconhecimento do lugar e do papel das crianças trabalhadoras deve servir para superar por contradição o cenário de não visibilidade, a partir do qual as crianças proletárias conseguem fazer avançar as concepções de família, os costumes sociais e as relações laborais em direção a um novo conceito de criança e infância, ou seja: como sujeito de direitos, independentemente de raça, cor e/ou origem social. Mesmo que as crianças proletárias não sejam reconhecidas e não tenham espaço na caracterização da infância na obra de Ariès (2015), e tampouco nas imagens pictóricas dos artistas da época, elas foram sim sujeitos históricos relevantes. A negação de sua condição de criança e da não fruição de sua infância contribuíram significativamente (por oposição), para o desenvolvimento da sociedade moderna e contemporânea, tornando-a mais humana. Prova disso é a vasta legislação trabalhista e educacional, que procuram erradicar o trabalho infantil e garantir o direito educacional das crianças pequenas nos dias de hoje.

\section{Referências}

ARIÈS, P. História social da criança e da família. $2^{\mathrm{a}}$ edição. Rio de Janeiro: LTC, 2015.

ARIÈS, P. e DUBY, G. História da vida privada 1. São Paulo: Companhia das Letras, 2009a.

ARIÈS, P.; DUBY, G. História da vida privada 2: da Europa feudal à Renascença. São Paulo: Companhia das Letras, 2009b.

ARIÈS, P.; DUBY, G. História da vida privada 3: do Renascença ao Século das Luzes. São Paulo: Companhia das Letras, 2009c.

ARIÈS, P.; DUBY, G. História da vida privada 4: da Revolução Francesa à Primeira Guerra. São Paulo: Companhia das Letras, 2009d. 
ARIÈS, P.; DUBY, G. História da vida privada 5: da Primeira Guerra a nossos dias. São Paulo: Companhia das Letras, 2009e.

CAMBI, F. História da pedagogia. São Paulo: Editora UNESP, 2001.

DEL PRIORE, M. (org.) História das crianças no Brasil. 6ª . ed. São Paulo: Contexto, 2007.

DOBB, M. A evolução do capitalismo. 9ª . edição. Rio de Janeiro: Zahar Editores, 1983.

ENGELS, F. A situação da classe trabalhadora na Inglaterra. São Paulo: Boitempo, 2010.

HERMIDA, J. F. História social da criança proletária: as infâncias roubadas nos processos de reprodução do capital nos séculos XVIII e XIX. Tese de Professor Titular. UFPB. João Pessoa, 2020a.

HERMIDA, J. F. História social da criança proletária: contribuições da obra de Friedrich Engels para a compreensão do tema. Revista HISTEDBR On-line, Campinas, SP, v. 20, p. e020058, 2020b. DOI: 10.20396/rho.v20i0.8660883. Disponível em: https://periodicos.sbu.unicamp.br/ojs/index.php/histedbr/article/view/8660883. Acesso em: 11 mar. 2021.

HOBSBAWM, E. Mundos do trabalho: novos estudos sobre a história operária. $6^{\text {a }}$. ed. São Paulo: Paz e Terra, 2015a.

HOBSBAWM, E. Os trabalhadores. Estudos sobre a história do operariado. $5^{\text {a }}$. ed. São Paulo: Paz e Terra, 2015b.

HOBSBAWM, E. A era do capital 1848-1875. 11ª . ed. São Paulo: Paz e Terra, 2005.

HOBSBAWM, E. A era das Revoluções 1789-1848. 14a . ed. São Paulo: Paz e Terra, 2001.

KLEIN, L. R. Cadê a criança do Ariès que estava aqui? A fábrica comeu... Anais do IX Seminário Nacional de Estudos e Pesquisas "HISTEDBR”. João Pessoa, julho de 2012.

KUHLMANN Jr., M. Infância e Educação Infantil: uma abordagem histórica. Porto Alegre: Editora Mediação, 1998.

LIMA, M. P. Infância e educação: um olhar sobre as crianças nas pesquisas científicas. Revista Educação e Cultura Contemporânea, vol. 11, n 3, 2014.

MARX, K. Manuscritos econômico-filosóficos. São Paulo: Boitempo, 2010.

MARX, K. O capital. Livro 1: o processo de produção do capital. São Paulo: Boitempo, 2013.

SAVIANI, D. Pedagogia histórico-crítica. 11ª . ed. revisada. Campinas: Autores Associados, 2013. 
Polyphonía, v. 32/2, jul./dez. 202138

THOMPSON E. P. A formação da classe operária inglesa I. A árvore da liberdade. Rio de Janeiro: Paz e Terra, 1987a.

THOMPSON E. P. A formação da classe operária inglesa II. A maldição de Adão. Rio de Janeiro: Paz e Terra, 2012a.

THOMPSON E. P. A formação da classe operária inglesa III. A força dos trabalhadores. 2a . ed. São Paulo: Paz e Terra, 2012b. 